\title{
Autopsy TNM Finding
}

National Cancer Institute

\section{Source}

National Cancer Institute. Autopsy TNM Finding. NCI Thesaurus. Code C48882.

TNM staging performed on autopsy. 